\title{
Evolution and taxonomy of nematode-associated entomopathogenic bacteria of the genera Xenorhabdus and Photorhabdus: an overview
}

\author{
Ewa Sajnaga ${ }^{1}$ (ID) - Waldemar Kazimierczak ${ }^{1}$ (D)
}

Received: 23 October 2019 / Accepted: 5 December 2019/Published online: 10 January 2020

(C) The Author(s) 2020

\begin{abstract}
Entomopathogenic bacteria from the genera Photorhabdus and Xenorhabdus are closely related Gram-negative bacilli from the family Enterobacteriaceae ( $\gamma$-Proteobacteria). They establish obligate mutualistic associations with soil nematodes from the genera Steinernema and Heterorhabditis to facilitate insect pathogenesis. The research of these two bacterial genera is focused mainly on their unique interactions with two different animal hosts, i.e. nematodes and insects. So far, studies of the mutualistic bacteria of nematodes collected from around the world have contributed to an increase in the number of the described Xenorhabdus and Photorhabdus species. Recently, the classification system of entomopatogenic nematode microsymbionts has undergone profound revision and now 26 species of the genus Xenorhabdus and 19 species of the genus Photorhabdus have been identified. Despite their similar life style and close phylogenetic origin, Photorhabdus and Xenorhabdus bacterial species differ significantly in e.g. the nematode host range, symbiotic strategies for parasite success, and arrays of released antibiotics and insecticidal toxins. As the knowledge of the diversity of entomopathogenic nematode microsymbionts helps to enable the use thereof, assessment of the phylogenetic relationships of these astounding bacterial genera is now a major challenge for researchers. The present article summarizes the main information on the taxonomy and evolutionary history of Xenorhabdus and Photorhabdus, entomopathogenic nematode symbionts.
\end{abstract}

Keywords Xenorhabdus $\cdot$ Photorhabdus $\cdot$ Entomopathogenic bacteria $\cdot$ Nematode symbionts $\cdot$ Evolution $\cdot$ Taxonomy

\section{Introduction}

Enthomopathogenic bacteria are widespread in nature and include mainly members of the genera Bacillus, Peanibacillus, Brevibacillus, Serratia, Pseudomonas, Xenorhabdus, and Photorhabdus. As obligate or facultative insect pathogens, entomopathogenic bacteria display different host ranges and mechanisms of infection; however, all of them have similar abilities to produce a huge repertoire of virulence factors to overcome insect immune responses and host microbiota

Ewa Sajnaga esajnaga@kul.pl

1 John Paul II Catholic University of Lublin, Centre for Interdisciplinary Research, Laboratory of Biocontrol Application and Production of EPN, Konstantynów 1J, 20-708 Lublin, Poland
(Boemare and Tailliez 2009; Glare et al. 2017). Photorhabdus and Xenorhabdus bacteria exhibit another essential feature: as obligate symbionts of infective juveniles (IJs) of entomopathogenic nematodes (EPNs) from the genera Steinernema and Heterorhabditis, respectively, they spend some part of their lives inside nematodes using them as a vector for efficient infection of insects (Goodrich-Blair and Clarke 2007; Koppenhöfer and Gaugler 2009; Stock 2015). Nematodes from the genus Sternainema carry symbiotic bacteria in a specialized vesicle called the receptacle, which is placed in the anterior part of the gut. In turn, Heterorhabditis nematodes, which do not have such a specialized structure, use their intestinal lumen to harbor bacteria (Fig. 1) (Bird and Akhurst 1983; Boemare 2002; Snyder et al. 2007). The life cycle of all EPN microsymbionts is similar and can be divided into three phases: phoretic in the nematode host, pathogenic in the insect body, and saprophytic in the insect cadaver (Ciche et al. 2006; Herbert and Goodrich-Blair 2007; Stock and 

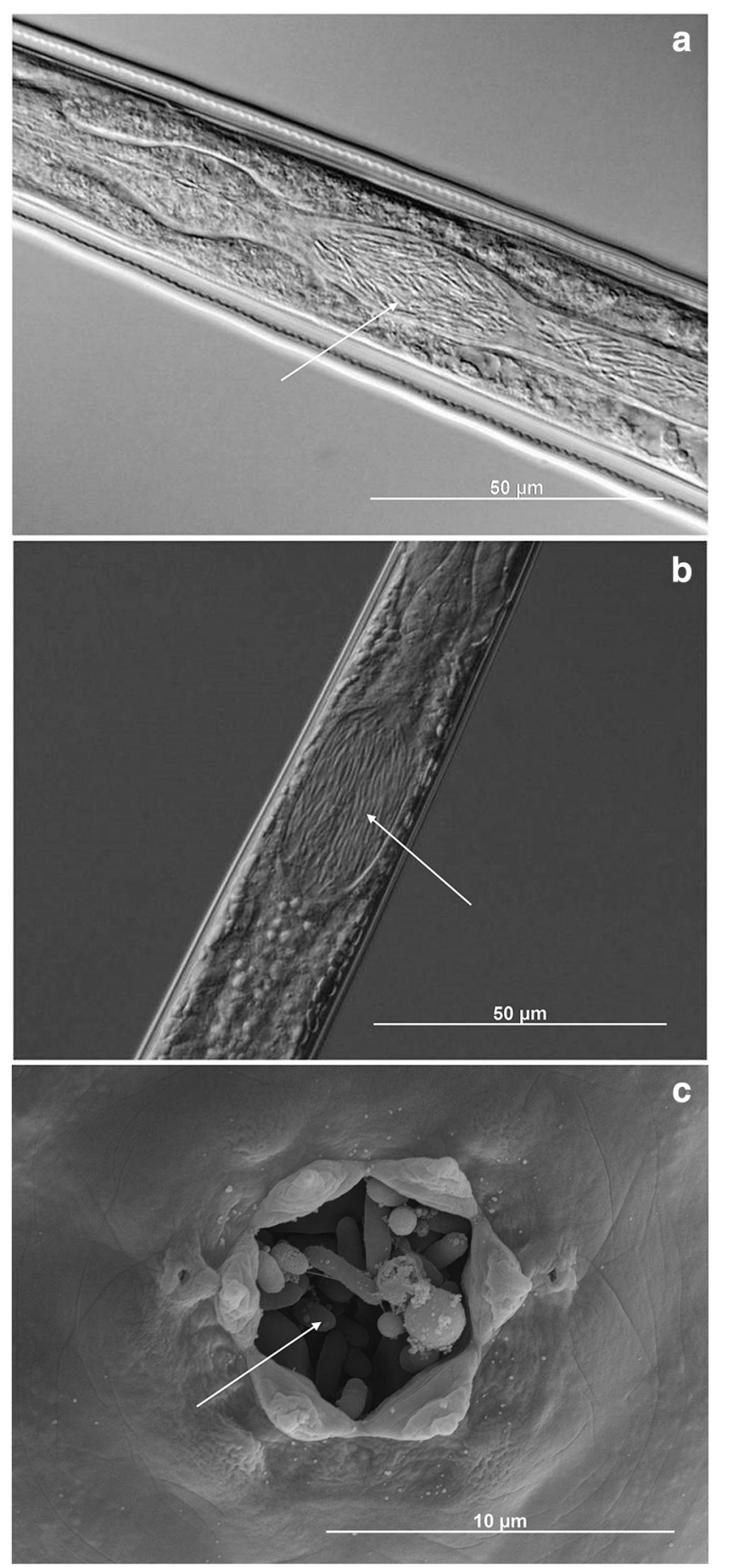

Fig. 1 a Anterior end of a H. megidis infective juvenile. Photorhabdus temperata rods visible (arrow) inside the whole lumen of the intestine. b Anterior end of a $S$. intermedium infective juvenile. Xenorhabdus bovienii rods visible (arrow) inside a bacterial pouch. c 1st generation female of $H$. zealandica. Photorhabdus temperata rods visible (arrow) inside the nematode mouth. Scale bars: as on images. The images were obtained using differential interference contrast microscope $(\mathbf{a}, \mathbf{b})$ and scanning electron microscope (c)

Goodrich-Blair 2008; Koppenhöfer and Gaugler 2009). In addition, some Photorhabdus bacteria have been identified as opportunistic pathogens of humans; however, the mechanism of infection is not known yet (see chapter 7 for details). There is also a report on a bacterial strain classified as Photorhabdus luminescens, which causes rare neonatal bacteremia and cutaneous lesions (Dutta et al. 2018).

The Xenorhabdus and Photorhabdus bacteria are easy to cultivate in the laboratory; isolated from infected insects or from the intestinal lumen of IJs of nematodes as their natural habitats, they grow fast in Luria-Bertani medium, with a doubling time of approx. $2 \mathrm{~h}$. In fact, EPN symbiotic bacteria have never been found living freely in the soil; however, they have been detected in the bacterial biota of the insect larvae in metagenomic studies (Osimani et al. 2018).

EPNs together with their bacterial symbionts are well known for their long-term use in biological and integrated pest management since they display insecticidal activity against a wide range of soil-dwelling insect and other arthropods (Poinar and Grewal 2012; Hiltpold 2015). Furthermore, studies have advanced these organisms as a relevant biological model in fields of soil ecology, symbiotic relationships, and evolutionary biology (Stock 2005, 2015; Campos-Herrera et al. 2012). Recently, investigations of the virulence mechanisms and secondary metabolites of the Xenorhabdus and Photorhabdus bacteria have been aimed at their potential to be used for management of agricultural pests (Hinchliffe et al. 2010; Zhang et al. 2012; Kumari et al. 2015; Stock et al. 2017), as mosquito control repellents and feeding-deterrents (Yooyangket et al. 2018; Kajla et al. 2019), and in medical applications as a response to the need for novel antibiotics (Tobias et al. 2018; Xue et al. 2018).

\section{General characteristic of the Xenorhabdus and Photorhabdus bacteria}

The Xenorhabdus and Photorhabdus bacteria belong to the family Enterobacteriaceae within Gammaproteobacteria (Imhoff 2005; Koppenhöfer 2007). They are not the only $\gamma$ Proteobacteria that establish mutualistic symbiosis with nematodes. Research data indicate that Moraxella osloensis (family Pseudomonadaceae) can enter symbiosis with a slugparasitizing nematode Phasmarhabditis hermaphrodita, whereas entomopathogenic Serratia sp. (family Enterobacteriaceae) have been found to associate with Oscheius and Caenorhabditis nematodes enabling their success as insect pathogens. Although these symbiotic associations seem not to be obligate, they suggest that the ability to engage in symbiosis with nematodes may have arisen several times during the evolution of $\gamma$-Proteobacteria (Husnik et al. 2011; Dillman et al. 2012).

Studies have established that the Photorhabdus and Xenorhabdus bacteria are phylogenetically close, in contrast to their EPN hosts Steinernema and Heterorhabditis, 
which represent distinct clades (Liu et al. 1997; Koppenhöfer 2007; Tailliez et al. 2010; Stock 2015). As demonstrated by phylogenetic trees based on housekeeping genes, the Xenorhabdus and Photorhabdus bacteria form tight sister groups, while the genus Proteus is their nearest neighbor (Fig. 2). Current evidence suggests that a common ancestor of these bacteria lived possibly about 200-500 million years ago and it was able to associate with both Steinernema and Heterorhabditis nematode hosts. However, under the selective pressure of maintenance of long-term mutualistic interactions with the nematodes host, two separate genera of bacteria displaying host specific associations have evolved (Boemare 2002; Chaston et al. 2011). Studies have also revealed that a general trend in the EPN bacterial phylogeny is the increasing virulence associated with evolutionary trade-off between virulence and bacteriocin production abilities (Blackburn et al. 2016; Meli and Bashey 2018; Bhattacharya et al. 2019).

Phenotypically, the Xenorhabdus and Photorhabdus bacteria are defined as Gram-negative, facultatively anaerobic, non-spore forming rods. They are considered to be distinctive from other members of the family Enterobacteriacae in the same traits, including their inability to reduce nitrate to nitrite, which is the major positive feature of this family (Boemare 2002; Imhoff 2005). Another unique feature of the Xenorhabdus and Photorhabdus bacteria is their phenotypic variation, i.e. the existence of the primary and secondary form; however, the environmental stimuli and the role of the switch between two cell types in the life cycle of EPN symbionts are unclear (Boemare and Akhurst 1988). Recently, new information about differences in the transcriptome level between the two cell forms has contributed to formulation of a hypothesis that primary cells, which are not able to reassociate with nematodes, can live freely in the rhizosphere (Eckstein et al. 2019). Only bacteria of the genus Photorhabdus are positive for catalase and bioluminescence, thus they can be easily differentiated from bacteria of the genus Xenorhabdus by these two traits. The bioluminescence ability is the most curious phenotypic characteristic of the Photorhabdus bacteria. In fact, Photorhabdus are the only known bioluminescent terrestrial bacteria that are able to produce light; however, the function of this trait in Photorhabdus is unclear. Peat et al. (2010) showed a decline in bioluminescence intensity throughout the evolution of the Photorhabdus bacteria, supporting the hypothesis that this feature was acquired by their ancestor living in an aquatic environment but now is gradually being lost under terrestrial selection pressure. This agrees with the idea of bioluminescence in Photorhabdus as a non-functional evolutionary remnant that has not had enough time to be lost, as proposed earlier by Peat and Adams (2008).
3 Molecular diversity among EPN symbionts

To assess the genetic diversity of the Xenorhabdus and Photorhabdus bacteria, comparison of molecular typing profiles and gene sequences has been frequently used (e.g. Maiden et al. 1998; Tailliez et al. 2006; Adams et al. 2006). Recently, whole-genome analyses increasingly support studies on the diversity, biology, and evolutionary relationships of EPN bacteria (Murfin et al. 2012). Indeed, consideration of full genome sequences of different EPN microsymbionts has uncovered the large genomic divergence among the Xenorhabdus and Photorhabdus bacteria (Wilkinson et al. 2009; Chaston et al. 2011; Murfin et al. 2015a). It is now clear that the genomes of EPN bacteria encode diverse antibiotics, adhesins, hemolysins, proteases, and lipases, which are crucial for successful host invasion and bioconversion of the insect cadaver (Bode 2009). In fact, analysis of the P. luminescens TT01 genome revealed that nearly $6 \%$ of the genome sequences encode secondary metabolites, highlighting the potential of these bacteria for discovery of new drugs (Duchaud et al. 2003). Studies have established that many virulence genes of the Xenorhabdus and Photorhabdus bacteria are located within pathogenicity islands, probably acquired by extensive horizontal transfer (Waterfield et al. 2002; Duchaud et al. 2003; Chaston et al. 2011). Genes coding for insecticidal toxins and host-induced stress protection are regarded to be conserved, in contrast to genes involved in production of antimicrobial molecules limiting the growth of competitors, which appear to be highly diverse among EPN bacteria, even within a single population (An et al. 2009; Meli and Bashey 2018). Similarly, genes involved in mutualistic associations of the bacteria with nematodes exhibit considerable variation (Chaston et al. 2011). The studies reviewed above suggest that, despite the close phylogenetic relationships and similar lifestyle, the Xenorhabdus and Photorhabdus bacteria under different evolutionary pressures exerted by their two animal hosts as well as the environment (especially competitors) have developed a great number of different ways of interacting with nematodes, which is an example evolutionary convergence.

Xenorhabdus bovienii seems to be the most diverse species among EPN bacteria; nevertheless, genomic studies confirmed its species status according to the current taxonomic criteria (Tailliez et al. 2010; Murfin et al. 2015b). Unlike other EPN bacteria spp., $X$. bovienii is a mutualist of several Steinernema spp. belonging to two distant phylogenetic clades (Table 1) (Spiridonov et al. 2004; Nadler et al. 2006). Studies have revealed that $X$. bovienii strains differ significantly in the genome content and fitness strategy; however, this is related to the diversity of bioactive molecules and their regulation rather than the use of different mechanisms for mutualistic relationships with the nematodes (Murfin et al. 2015a, b; Bisch et al. 2016; McMullen et al. 2017a). Moreover, analysis of the multiple genomes of 
Fig. 2 Maximum-likelihood phylogenetic tree of the type strains of Xenorhabdus and Photorhabdus species reconstructed from concatenated nucleotide sequences of four protein-coding genes recA, dnaN, glt $X$, and $g y r B$ (2823 bp). The numbers at the nodes show bootstrap values higher than $70 \%$ based on 1000 replications. The tree was rooted using Proteus mirabilis as an outgroup. Scale bar: 0,02 nucleotide substitutions per sequence position. The tree was inferred using MEGA6

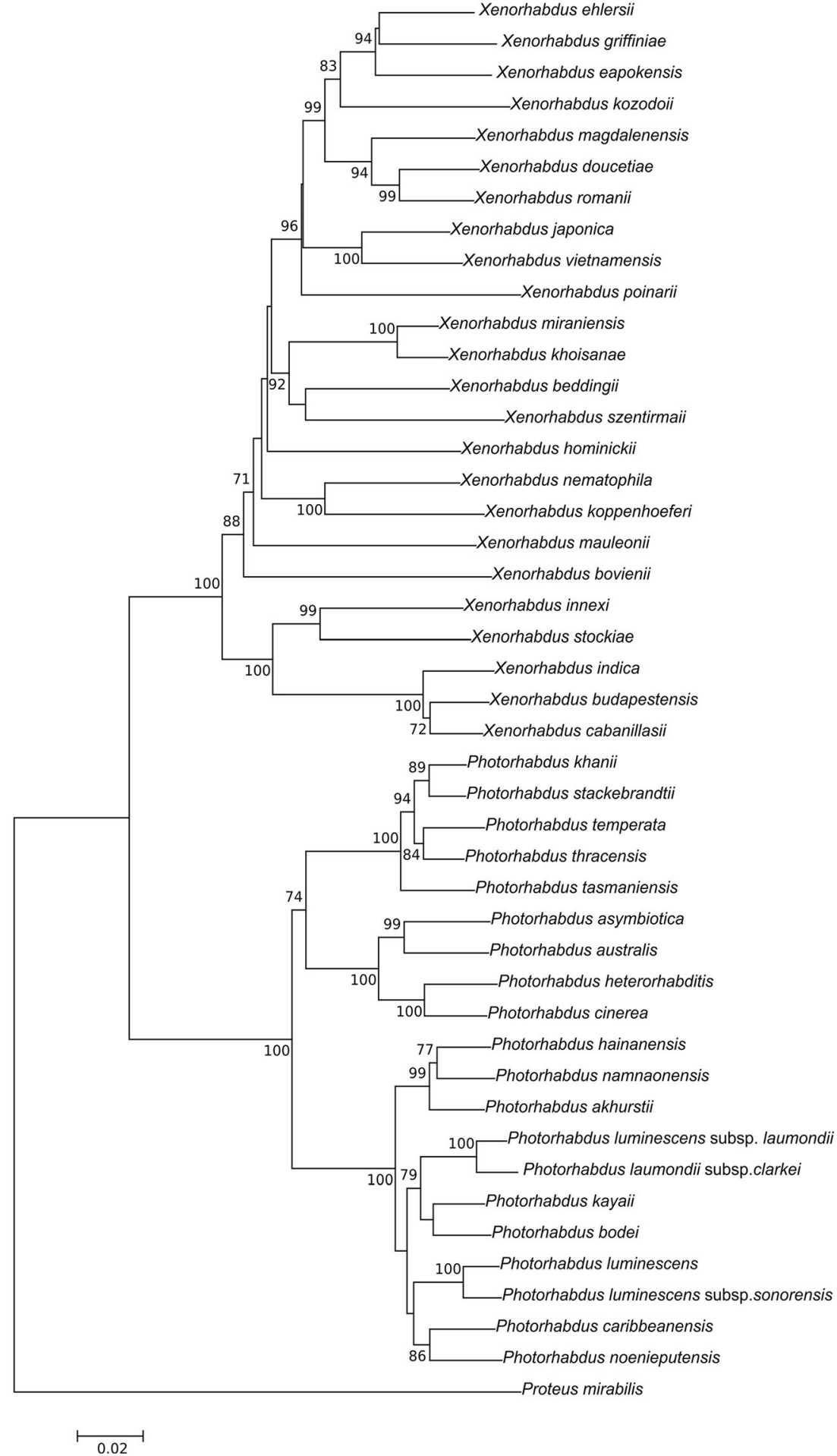

$X$. bovienii as well as other EPN microsymbionts has supported their ecotype model of speciation. The ecotype, recognizing specific relationships between genes and the environment, is generally defined as an evolutionarily distinct group of strains within bacterial species that play a discrete ecological role (Koeppel et al. 2008). Since Xenorhabdus and Photorhabdus strains display specialization in producing particular bioactive compounds to interact with specific nematodes, despite being members of a single species, it is suggested that it is the ecotype definition that should be used to describe the fundamental units of their diversity (Chaston et al. 2011; Murfin et al. 2015a). 
Table 1 List of currently described species in the genus Xenorabdus (Thomas and Poinar 1979) and their nematode symbionts

\begin{tabular}{ll}
\hline Xenorhabdus species & References \\
\hline X. beddingii & Akhurst and Boemare 1988 \\
X. bovienii & Akhurst and Boemare 1988
\end{tabular}

X. budapestensis
X. cabanillasii
X. doucetiae
X. ehlersii
X. eapokensis
X. griffiniae

$X$. hominickii

$X$. indica

$X$. innexi

X. ishibashii

X. japonica

X. khoisanae

X. koppenhoeferi

X. kozodoii

X. magdalenensis

X. mauleonii

X. miraniensis

X. nematophila

X. poinarii

X. romanii

X. stockiae

X. szentirmaii

X. thuongxuanensis

$X$. vietnamensis

a nomina nuda
Steinernema species being a symbiont

undescribed species

S. feltiae, S. kraussei, S. affinae,

S. intermedium, $S$. weiseri, $S$. silvaticum,

S. sichuanense,

S. nguyeni, S. poinari, S. tbilisiensis, S. jollieti,

S. puntauvense, S. oregeonense, S. litorale

S. bicornutum, $S$. ceratophorum

S. riobrave

S. diaprepesi

S. longicaudum (S. serratum ${ }^{\mathrm{a}}$ )

S. eapokensis

S. hermaphroditum, undescribed species

S. karii, S. monticolum

S. thermophilum a S. abbasi

S. scapterisci

S. aciari

S. kushidai

S. khoisanae,

S. jeffreyense, S. saccharii

S. scarabaei

S. arenarium

S. australe

undescribed species

undescribed species

S. carpocapsae

S. glaseri, S. cubanum

S. puertoricense

S. siamkayai

S. rarum

S. sangi

S. sangi

\section{Specificity of symbiotic relationships and coevolution between bacterial symbionts and their nematode host}

In the symbiotic interactions between nematodes and bacteria, the strong specificity favoring symbionts with the most beneficial traits facilitates successful transmission of such a bacteria-nematode pair from one insect host to another (Adams et al. 2006). It is assumed that each species of the genus Steinernema establishes symbiosis with only one Xenorhabdus species; in turn, many Xenorhabdus species can be associated with several nematode species. In contrast, the symbiotic Heterorhabditis-Photorhabdus relationships are more flexible: many species, both bacteria and nematodes, are able to engage in symbiotic associations with multiple species of symbiotic partners (Koppenhöfer 2007; Koppenhöfer and Gaugler 2009). While plenty of data support this specificity pattern, the mechanisms underlying it remain to be elucidated (Herbert and Goodrich-Blair 2007; Hillman and GoodrichBlair 2016).

Laboratory studies on the specificity of symbiotic associations are usually based on removal of native microsymbionts followed by re-association of nematode-bacterium pairs with non-native bacteria. Such experiments demonstrated strong 
partner preference, however with the potential for horizontal transfer of symbionts between different species of nematodes, depending on the bacterium-nematode pair used (e. g. Sicard et al. 2004; Sicard et al. 2005; Chapuis et al. 2009; Murfin et al. 2015b; McMullen et al. 2017b; Kazimierczak et al. 2017; Sajnaga et al. 2018). In fact, the bacterial hostswitching between nematode species, even those representing different clades, seems to be rare but possible, especially that associations of nematodes with new symbiotic partners may enable colonization of new niches or extend one by conferring significant fitness benefits (Henry et al. 2013; Maher et al. 2017). Nevertheless, the microsymbiont switching has most often a detrimental effect on the nematode host because association with non-cognate symbionts results in a decline in their reproduction fitness, symbiont carriage, and virulence. As expected, nematode-bacterium pairs with bacteria closely related to its native microsymbiont are more efficient in terms of reproductive fitness and virulence than those with a distantly related microsymbiont. The reproductive success of the nematode associated with non-cognate bacteria is also strongly inversely correlated with the phylogenetic distance between nematodes being a donor and a recipient of microsymbionts, confirming that the nematode host diversity strongly influences coadaptation between symbiotic partners (Murfin et al. 2015b; McMullen et al. 2017b).

It is known that associations between obligate mutualists, involving fulfillment of their needs, often result in cospeciation or a larger phenomenon - coevolution, where symbionts share adaptive changes and their evolutionary history is congruent. To date, few studies based on comparisons of the gene phylogenies of the nematode-bacterium partners have been conducted to assess co-speciation or co-evolution events. Using a single-gene approach, Maneesakorn et al. (2011) provided evidence for a co-evolutionary pattern of relationships between a majority of the Photorhabdus and Heterorhabditis symbiotic associations tested; however, processes such us host switching and host duplication of bacteria, which can create incongruence between phylogenies of symbiotic partners, were detected as well. In contrast, using a multigene approach, Lee and Stock (2010b) found little evidence for the coevolution between Xenorhabdus bacteria and Steinernema nematodes. Furthermore, this analysis suggested that the host switching of the microsymbiont occurred rampantly in the evolutionary history of Xenorhabdus. Then, several studies have revealed cospeciation events as well as the ability of microsymbionts to transfer between distantly related nematodes in the mutualistic Xenorhabdus/Steinernema associations (Lee and Stock 2010b; Murfin et al. 2015b; Dreyer et al. 2017; Bhat et al. 2018). There are several reasons why the processes of host switching, could culminate in the evolutionary history of the Xenorhabdus and Photorhabdus bacteria. EPNs are cosmopolitan animals often coexisting in the same ecological niche (Grewal et al. 1994; Půža and Mráček
2010). As they also have a wide insect host range, coinfections of the same insect by more than one EPN species is likely to occur in nature (Koppenhöfer and Kaya 1996; Peters 1996; Grewal et al. 1997). Additionally, within the insect host, symbiotic bacteria are physically separated from the nematode, which is not in common with most of the other mutualistic symbioses, where partners do not disassociate naturally. In fact, in the case of co-infection of an insect by different nematodes, their microsymbionts are free to associate with other nematodes (Adams et al. 2006). In this respect, it is suggested that host switching is an evolutionary phenomenon responsible for the spread of bacterial symbionts to different nematode hosts, enabling dissemination of phylogenetically conservative traits, which is also called ecological fitting (Maneesakorn et al. 2011; Stock 2015).

\section{Approaches used for taxonomy and identification of EPN symbiotic bacteria}

Initially, the symbiotic properties and some phenotypic features were the main criteria used to differentiate among Xenorhabdus and Photorhabdus bacteria and classify them into two separate groups (Thomas and Poinar 1979). Subsequently, a polyphasic approach was introduced to classify prokaryotes based on integration of different kinds of phenotypic and genotypic data. It was followed by $16 \mathrm{~S}$ rRNA gene sequence analysis and DNA/DNA hybridization (DDH), which have become "the gold standard" in the taxonomy of bacteria (Rosselló-Mora and Amann 2001; Stackebrandt et al. 2002; Stackebrandt and Ebers 2006). To accomplish the new species concept, the 16S rDNA sequence similarity threshold $97 \%$, later changed into $98.7 \%$, was applied in recognizing new species of EPN symbionts (Farmer et al. 1989; Boemare et al. 1993; Liu et al. 1997; Fischer-Le Saux et al. 1999). Additionally, the 70\% DDH threshold introduced by the ad hoc Committee on Reconciliation of Approaches of Bacterial Systematics (Wayne et al. 1987) and the $80 \%$ DDH threshold proposed by Vandamme et al. (1996) effectively complemented the minimal standards in the taxonomy of Xenorhabdus and Photorhabdus, respectively.

Meanwhile, the rapid development of the gene sequencing techniques changed the approach to the definition of bacterial species. It became apparent that using solely ribosomal subunit sequences for taxonomic purposes was not suitable due to their low variation and lateral gene transfer (LTG) among different bacterial species (Akhurst et al. 2004; Tailliez et al. 2006; Lee and Stock 2010a; Tailliez et al. 2010). To overcome this limitation, a more robust phylogenetic relationship framework for the Xenorhabdus and Photorhabdus bacteria was developed by comparing the sequences of genes coding for proteins with conserved function (Sergeant et al. 2006; An and Grewal 2010; Lee and Stock 2010a). Finally, multilocus 
sequence analysis (MLSA) of genes coding for proteins with conserved functions, called housekeeping genes, was widely adopted for inference of the phylogenetic relationships of nematode microsymbionts and gradually replaced the singlegene analysis and time-consuming DDH in identification and classification of these bacteria (Maiden et al. 1998; Stackebrandt et al. 2002; Glaeser and Kämpfer 2015). Nevertheless, the 16S rDNA sequence analysis is still a common approach for preliminary investigations of the genetic diversity of bacterial collections and for establishment of the genus status of newly isolated EPN bacterial strains (e.g. Kazimierczak et al. 2016, 2017; Godjo et al. 2018; Sajnaga et al. 2018). In 2010, Tailliez et al. (2010), by using concatenated sequences of four protein coding gene fragments: recA (recombinase A), gyrB (gyrase B), dnaN (DNA polymerase III subunit), and $g l t X$ (glutamyl-tRNA synthetase) for a thorough analysis of the EPN symbiont phylogeny, introduced the scheme of MLSA to identify EPN bacteria. Hence, the Xenorhbdus species was outlined as a collection of strains whose concatenated sequences of the housekeeping genes mentioned above (3396 bp) showed 97\% identity, whereas the same threshold delimitated the subspecies boundary for Photorhabdus strains to fit the more strict taxonomic system of this genus (Tailliez et al. 2010). To improve the robustness of the phylogenetic study of EPN bacteria, the fifth $\operatorname{infB}$ gene sequence was soon added to the MLSA scheme (Tailliez et al. 2012). Such comparative sequence analysis has been widely used for the last years for identification of many new bacterial isolates and has led to delineation of several new species and subspecies of EPN bacteria (e.g. Tailliez et al. 2010; Ferreira et al. 2013a, b; Kuwata et al. 2013; Orozco et al. 2013; Glaeser et al. 2017).

Currently, advancement of the DNA sequencing technology allows the use full genome sequences for taxonomic purposes (Auch et al. 2010; Lee et al. 2016). In fact, to delineate new bacterial species the replacement of DDH with pairwise genome sequence-derived similarity has been proposed by several authors (Chun et al. 2018). The power of genomotaxonomy has recently been demonstrated by Machado et al. (2018), who presented a high-resolution taxonomy of the genus Photorhabdus. In their study, consideration of two whole genome-based phylogenetic methods, i.e. orthologous average nucleotide identity (OrthoAni) and in silico DNA-DNA hybridization (isDDH), supported by traditional methods, such as MLSA, MALDI-TOF, and phenotypic tests, deeply revisited the genus Photorhabdus phylogeny.

\section{Changes in the taxonomy of Xenorhabdus and Photorhabdus - historical overview}

Symbiotic bacteria isolated from the nematode Steinernema carpocapse were described for the first time in 1965 (Poinar and Thomas 1965; Poinar and Thomas 1966). They were named Achromobacter nematophilus, later transferred to a newly created genus Xenorhbdus and renamed as Xenorhabdus nematophilus, and finally renamed as Xenorhabdus nematophila to comply with the bacteriological nomenclature (Thomas and Poinar 1979; Euzéby and Boemare 2000). Meanwhile, symbiotic glowing bacteria isolated from Heterorhabditis bacteriophora were included into the genus Xenorhabdus as Xenorhabdus luminescensens (Thomas and Poinar 1979). Therefore, up to 1993, there were only two bacterial species in the genus Xenorhabdus, i.e. Xenorhabdus nematophila (type species) and Xenorhabdus luminesces, which comprised symbionts of Steinernema and Heterorhabditis nematodes, respectively (Akhurst 1983; Akhurst and Boemare 1988; Boemare and Akhurst 1988; Farmer et al. 1989). However, the significant differences in the phenotypic and molecular traits between these two species resulted in the transfer of all Heterorhabditis nematode symbionts into a new genus Photorhabdus as Photorhabus luminescens (Boemare et al. 1993).

Although the genus Xenorhabdus was found to be more homogenous than Photorhabdus, it quickly became relatively rich in terms of the number of species (Akhurst et al. 1996). At first, using a polyphasic approach, 3 new species were described by elevating the $X$. nematophila subspecies to the species level, i.e. Xenorhabdus beddingi, Xenorhabdus poinarii, and Xenorhabdus bovienii (Akhurst 1983; Akhurst and Boemare 1988). The delineation of new species of EPN symbionts based on sequence data of single gene sequences continued in the next years, and in 2007 Koppenhöfer reported a list of 20 Xenorhabdus spp. The recognition of the last few Xenorhabdus species was linked with the application of MLSA and whole genome sequence data to EPN symbionts. Currently, 26 species representing the genus Xenorhabdus have been described (Table 1).

After establishment of the genus Photorhabdus in 1993, bacteria of the only species $P$. luminescens were divided into two groups, i.e. Heterorhabditis nematode symbionts and human clinical isolates (Akhurst et al. 1996). However, based on phylogenetic analysis of 16S rRNA gene sequences, another two species in the genus Photorhabdus were delineated in 1997, i.e. Photorhabdus temperata and Photorhabdus asymbiotica for some nematode symbionts and all bacteria isolated from human specimens, respectively (Lie et al. 1997; Fischer-Le Saux et al. 1999). Meanwhile, the stricter taxonomic system for the genus Photorhabdus bacteria contributed to creation of many new taxa with a status of subspecies (e.g. Fischer-Le Saux et al. 1999; Hazir et al. 2004; Tóth and Lakatos 2008; An and Grewal 2010, 2011). In 2010, after a deep revision of the genus Photorhabdus phylogeny based on MLSA, there were only 3 species in this genus: $P$. luminescens, $P$. temperata, and $P$. asymbiotica, but they comprised 9, 6, and 2 subspecies, respectively (Tailliez et al. 2010). The fourth species in the genus Photorhabdus, 
Photorhabdus heterorhabditis, was described by Ferreira et al. (2014) for bacterial symbionts of the nematode Heterorhabditis zealandica. Recently, based on wholegenome sequence data, Machado et al. (2018) proposed the elevation of most Photorhabdus subspecies to the species level and described one novel species - Photorhabdus bodei. At the time of writing, the genus Photorhabdus contained 19 species, 3 of which, i.e. Photorhabdus laumondii, $P$. luminescens, and Photorhabdus khani, include one or two subspecies (Table 2).
Table 2 List of currently described species in the genus Photorhabdus (Boemare et al. 1993) and their nematode symbionts

\begin{tabular}{|c|c|c|}
\hline Photorhabduss species & References & $\begin{array}{l}\text { Heterorhabditis species } \\
\text { being a symbiont }\end{array}$ \\
\hline P. akhurstii & $\begin{array}{l}\text { Fischer-Le Saux et al. 1999, } \\
\text { Machado et al. } 2018\end{array}$ & H. indica \\
\hline P. asymbiotica & $\begin{array}{l}\text { Fischer-Le Saux et al. 1999, } \\
\text { Akhurst et al. } 2004\end{array}$ & undescribed species \\
\hline P. australis & Akhurst et al. 2004, Machado et al. 2018 & H. gerrardi, H. indica \\
\hline P. bodei & Machado et al. 2018 & H. beicherriana \\
\hline P. caribbeanensis & Tailliez et al. 2010, Machado et al. 2018 & H. bacteriophora \\
\hline P. cinerea & $\begin{array}{l}\text { Tóth and Lakatos 2008, } \\
\text { Machado et al. } 2018\end{array}$ & $\begin{array}{l}\text { H. downesi, H. megidis, } \\
\text { H. bacteriophora }\end{array}$ \\
\hline P. hainanensis & Tailliez et al. 2010, Machado et al. 2018 & undescribed species \\
\hline P. heterorhabditis & Ferreira et al. 2014 & H. zealandica \\
\hline P. kayaii & Hazir et al. 2004, Machado et al. 2018 & H. bacteriophora \\
\hline P. khanii & Tailliez et al. 2010, Machado et al. 2018 & H. bacteriophora \\
\hline subsp. guanajuatensis & Machado et al. 2019 & H. atacamensis \\
\hline P. kleinii & $\begin{array}{l}\text { An and Grewal 2011, } \\
\text { Machado et al. } 2018\end{array}$ & $\begin{array}{l}\text { H. georgiana, } \\
\text { H. bacteriophora, }\end{array}$ \\
\hline $\begin{array}{l}\text { P. laumondii } \\
\text { subsp. clarkei }\end{array}$ & $\begin{array}{l}\text { Fischer-Le Saux et al. 1999, } \\
\text { Machado et al. } 2018\end{array}$ & $\begin{array}{l}\text { H. bacteriophora } \\
\text { H. bacteriophora }\end{array}$ \\
\hline subsp. laumondii & $\begin{array}{l}\text { Machado et al. } 2018 \\
\text { Fischer-Le Saux et al. } 1999 \text {, } \\
\quad \text { Machado et al. } 2018\end{array}$ & H. bacteriophora \\
\hline $\begin{array}{l}\text { P. luminescens } \\
\text { subsp. sonorensis }\end{array}$ & $\begin{array}{l}\text { Thomas and Poinar 1979, } \\
\text { Boemare et al. } 1993\end{array}$ & $\begin{array}{l}\text { H. bacteriophora, H. indica } \\
\text { H. sonorensis }\end{array}$ \\
\hline subsp. mexicana & $\begin{array}{l}\text { Orozco et al. } 2013 \\
\text { Machado et al. } 2019\end{array}$ & H. mexicana \\
\hline P. namnaonensis & $\begin{array}{l}\text { Glaser et al. } 2017, \\
\text { Machado et al. } 2018\end{array}$ & H. baujardi \\
\hline P. noenieputensis & $\begin{array}{l}\text { Ferreira et al. 2013, } \\
\text { Machado et al. } 2018\end{array}$ & H. indica, Heterorhabditis sp. \\
\hline P. stackebrandtii & $\begin{array}{l}\text { An and Grewal 2010, } \\
\text { Machado et al. } 2018\end{array}$ & H. bacteriophora, H. georgiana \\
\hline P. tasmanensis & $\begin{array}{l}\text { Tailliez et al. } 2010 \text {, } \\
\text { Machado et al. } 2018\end{array}$ & H. zealandica, H. marelatus \\
\hline P. temperata & $\begin{array}{l}\text { Fischer-Le Saux et al. 1999, } \\
\text { Machado et al. } 2018\end{array}$ & $\begin{array}{l}\text { H. megidis, } H \text {. downesi, } \\
\text { H. zealandica }\end{array}$ \\
\hline P. thracensis & $\begin{array}{l}\text { Hazir et al. 2004, } \\
\text { Tailliez et al. 2010, } \\
\text { Machado et al. } 2018\end{array}$ & H. bacteriophora \\
\hline
\end{tabular}




\section{Photorhabdus bacteria with ability to infect both insects and humans}

A distinctive feature of some Photorhabdus bacteria is their pathogenicity to humans (Gerrard et al. 2004; Hapeshi and Waterfield 2017). Over a dozen human cases of Photorhabdus soft tissue infections and disseminated bacteremia have been documented so far, but many more are probably misdiagnosed (Gerrard et al. 2011; Gerrard and Stevens 2017). The first human pathogen from the genus Photorhabdus was isolated from a patient with a leg ulcer in the USA in 1989 (Farmer et al. 1989). This was followed by isolation of other Photorhabdus bacteria from human specimens in the USA and Australia (Gerrard et al. 2003). Since it was initially believed that these bacteria were not able to establish symbiosis with nematodes, the new species created for them was named $P$. asymbiotica to emphasize this feature (Fischer-Le Saux et al. 1999). However, in 2006, symbionts of the clinical Photorhabdus strain, i.e. heterorhabditid nematodes, were described and classified as Heterorhabditis gerrardi (Gerrard et al. 2004; Gerrard et al. 2006; Plichta et al. 2009). Thus, it is now accepted that human pathogenic Photorhabdus bacteria are able to form a mutualistic relationships with Heterorhabditis nematodes to infect insects efficiently, like other Photorhabdus nematode symbionts. Currently, two species: P. asymbiotica and $P$. australis comprise both clinical and entomopathogenic Photorhabdus strains derived from various locations (Kuwata et al. 2008; Thanwisai et al. 2012).

To address the particular life style of Photorhabdus human pathogens, their diversity and evolutionary relationships have been intensively explored by implementing whole genome sequencing and transcriptomic analysis. It was found that $P$. asymbiotica and $P$. australis bacteria have a relatively small genome, compared to that of $P$. luminesces (the closest relative), and display lower diversity of insecticidal toxins. The existence of many supplementary plasmids and pathogenicity islands in the genome has also been shown (Wilkinson et al. 2009, 2010). Current evidence suggests that the switch of these bacteria from nematodes to humans was facilitated by virulence genes (necessary for insect host infection) already present in the genome, as well as additional virulence factors (appropriate for infection of mammalian cells) acquired by horizontal transfer from other human pathogens (Hapeshi and Waterfield 2017). Unlike other species of the genus Photorhabdus, P. asymbiotica and P. australis can grow at $37^{\circ} \mathrm{C}$, undergoing the metabolic shift to adapt their metabolisms to the mammalian host (Mulley et al. 2015). Despite the considerable effort, the mechanisms of transmission of Photorhabdus bacteria to the human body are still unclear. The most probable scenario is that the nematode vector may penetrate the human skin and transmit microsymbionts, thereby causing infections (Hapeshi and Waterfield 2017).

\section{Conclusion}

The symbiotic bacteria of entomopathogenic nematodes emerged as a relevant model to study microorganism-host interactions. Although much interest in the Xenorhabdus and Photorhabdus bacteria has been historically driven by their symbiotic associations with nematodes, it is now clear that the uncovered richness of their secondary metabolites will accelerate investigations of these bacilli. Based on the recent advances in molecular phylogeny associated with the increasing number of available genes and genome sequences, the taxonomy of the symbiotic bacteria of entomopathogenic nematodes has been reassessed, with elevation of many subspecies to the species level and creation of new taxa. However, the current knowledge of the diversity, genealogy, and specificity of symbiotic relationships of Photorhabdus and Xenorhabdus bacteria with nematodes remains limited. In fact, despite the gradual identification of new EPN microsymbionts, mutualists of many existing nematode species have not been described yet. Therefore, substantial efforts should be made to improve the knowledge of the distribution of Xenorhabdus and Photorhabdus species linked to the host and geographic origin. It seems that implementation of whole genome-based phylogenetic methods can particularly provide ample information about the basic features and origin of these bacterial genera.

Acknowledgments This work was supported by the Polish Ministry of Science and European Union from the European Regional Development Fund under the Operational Programme Development of Eastern Poland 2007-2013 (POPW.01.03.00-06-003/09-00).

Open Access This article is licensed under a Creative Commons Attribution 4.0 International License, which permits use, sharing, adaptation, distribution and reproduction in any medium or format, as long as you give appropriate credit to the original author(s) and the source, provide a link to the Creative Commons licence, and indicate if changes were made. The images or other third party material in this article are included in the article's Creative Commons licence, unless indicated otherwise in a credit line to the material. If material is not included in the article's Creative Commons licence and your intended use is not permitted by statutory regulation or exceeds the permitted use, you will need to obtain permission directly from the copyright holder. To view a copy of this licence, visit http://creativecommons.org/licenses/by/4.0/.

\section{References}

Adams BJ, Fodor A, Koppenhöfer HS, Stackebrandt E, Stock PS, Klein MG (2006) Biodiversity and systematics of nematode-bacterium entomopathogens. Biol Control 37:32-49

Akhurst RJ (1983) Taxonomic study of Xenorhabdus, a genus of bacteria symbiotically associated with insect pathogenic nematodes. Int $\mathrm{J}$ Syst Bacteriol 33(1):38-45

Akhurst RJ, Boemare NE (1988) A numerical taxonomic study of the genus Xenorhabdus (Enterobacteriaceae) and proposed elevation of 
the subspecies of $X$. nematophilus to species. J Gen Microbiol 134(7):1835-1845

Akhurst RJ, Mourant RG, Baud L, Boemare NE (1996) Phenotypic and DNA relatedness between nematode symbionts and clinical strains of the genus Photorhabdus (Enterobacteriaceae). Int J Syst Bacteriol 46(4):1034-1041

Akhurst RJ, Boemare NE, Janssen PH, Peel MM, Alfredson DA, Beard CE (2004) Taxonomy of Australian clinical isolates of the genus Photorhabdus and proposal of Photorhabdus asymbiotica subsp. asymbiotica subsp. nov. and P. asymbiotica subsp. australis subsp. nov. Int J Syst Evol Microbiol 54(4):1301-1310

An R, Grewal PS (2010) Photorhabdus temperata subsp. stackebrandtii subsp. nov. (Enterobacteriales: Enterobacteriaceae). Curr Microbiol 61(4):291-297

An R, Grewal PS (2011) Photorhabdus luminescens subsp. kleinii subsp. nov. (Enterobacteriales: Enterobacteriaceae). Curr Microbiol 62(2): 539-543

An R, Sreevatsan S, Grewal PS (2009) Comparative in vivo gene expression of the closely related bacteria Photorhabdus temperata and Xenorhabdus koppenhoeferi upon infection of the same insect host, Rhizotrogus majalis. BMC Genomics 10 (1):433

Auch AF, von Jan M, Klenk HP, Göker MD (2010) Digital DNA-DNA hybridization for microbial species delineation by means of genome-to-genome sequence comparison. Stand Genomic Sci 28: $117-134$

Bhat AH, Chaubey AK, Puza V (2018) The first report of Xenorhabdus indica from Steinernema pakistanense: co-phylogenetic study suggests co-speciation between $X$. indica and its steinernematid nematodes. J Helminthol 93(1):81-90

Bhattacharya A, Toro Díaz VC, Morran LT, Bashey F (2019) Evolution of increased virulence is associated with decreased spite in the insectpathogenic bacterium Xenorhabdus nematophila. Biol Lett 15(8): 20190432

Bird AF, Akhurst RJ (1983) The nature of the intestinal vesicle in nematodes of the family Steinernematidae. Int J Parasitol 13(6):599-606

Bisch G, Ogier JC, Médigue C, Rouy Z, Vincent S, Tailliez P, Givaudan A, Gaudriault S (2016) Comparative genomics between two Xenorhabdus bovienii strains highlights differential evolutionary scenarios within an entomopathogenic bacterial species. Genome Biol Evol 8(1):48-60

Blackburn D, Wood PL, Burk TJ, Crawford B, Wright SM, Adams BJ (2016) Evolution of virulence in Photorhabdus spp., entomopathogenic nematode symbionts. Syst Appl Microbiol 39(3):173-179

Bode HB (2009) Entomopathogenic bacteria as a source of secondary metabolites. Curr Opin Chem Biol 13(2):224-230

Boemare NE (2002) Biology, taxonomy and systematics of Photorhabdus and Xenorhabdus. In: Gaugler R (ed) Entomopathogenic nematology. CABI Publishing, New York, pp $35-56$

Boemare NE, Akhurst RJ (1988) Biochemical and physiological characterization of colony form variants in Xenorhabdus spp. (Enterobacteriaceae). J Gen Microbiol 134:751-761

Boemare N, Tailliez P (2009) Molecular approaches and techniques for the study of entomopathogenic bacteria. In: Stock P, Vandenberg J, Glazer I, Boemare N (eds) Insect pathogens: molecular approaches and technique. CABI Publishing, pp 32-49

Boemare NE, Akhurst RJ, Mourant RG (1993) DNA relatedness between Xenorhabdus spp. (Enterobacteriaceae), symbiotic bacteria of entomopathogenic nematodes, and a proposal to transfer Xenorhabdus luminescens to a new genus, Photorhabdus gen. nov. Int J Syst Bacteriol 43(2):249-255

Campos-Herrera R, Barbercheck M, Hoy CW, Stock SP (2012) Entomopathogenic nematodes as a model system for advancing the frontiers of ecology. J Nematol 44(2):162-176
Chapuis E, Emelianoff V, Paulmier V, Le Brun N, Pages S, Sicard M, Ferdy JB (2009) Manifold aspects of specificity in a nematodebacterium mutualism. J Evol Biol 22:2104-2117

Chaston JM, Suen G, Tucker SL, Andersen AW, Bhasin A, Bode E, Bode HB, Brachmann AO, Cowles CE, Cowles KN, Darby C, de Léon L, Drace K, du Z, Givaudan A, Herbert Tran EE, Jewell KA, Knack JJ, Krasomil-Osterfeld KC, Kukor R, Lanois A, Latreille P, Leimgruber NK, Lipke CM, Liu R, Lu X, Martens EC, Marri PR, Médigue C, Menard ML, Miller NM, Morales-Soto N, Norton S, Ogier JC, Orchard SS, Park D, Park Y, Qurollo BA, Sugar DR, Richards GR, Rouy Z, Slominski B, Slominski K, Snyder H, Tjaden BC, van der Hoeven R, Welch RD, Wheeler C, Xiang B, Barbazuk B, Gaudriault S, Goodner B, Slater SC, Forst S, Goldman BS, Goodrich-Blair H (2011) The entomopathogenic bacterial endosymbionts Xenorhabdus and Photorhabdus: convergent lifestyles from divergent genomes. PLoS One 6(11):e27909

Chun J, Oren A, Ventosa A, Christensen H, Arahal DR, da Costa MS, Rooney AP, Yi H, Xu XW, De Meyer S, Trujillo ME (2018) Proposed minimal standards for the use of genome data for the taxonomy of prokaryotes. Int J Syst Evol Microbiol 68(1):461-466

Ciche TA, Darby C, Ehlers R-U, Forst S, Goodrich Blair H (2006) Dangerous liaisons: the symbiosis of entomopathogenic nematodes and bacteria. Biol Control 38:22-46

Dillman AR, Chaston JM, Adams BJ, Ciche TA, Goodrich-Blair H, Stock SP, Sternberg PW (2012) An entomopathogenic nematode by any other name. PLoS Pathog 8(3):e1002527

Dreyer J, Malan AP, Dicks LMT (2017) Three novel XenorhabdusSteinernema associations and evidence of strains of $X$. khoisanae switching between different clades. Curr Microbiol 74(8):938-942

Duchaud E, Rusniok C, Frangeul L, Buchrieser C, Givaudan A, Taourit S, Bocs S, Boursaux-Eude C, Chandler M, Charles JF, Dassa E, Derose R, Derzelle S, Freyssinet G, Gaudriault S, Medigue C, Lanois A, Powell K, Siguier P, Vincent R, Wingate V, Zouine M, Glaser P, Boemare N, Danchin A, Kunst F (2003) The genome sequence of the entomopathogenic bacterium Photorhabdus luminescens. Nat Biotechnol 21:1307-1313

Dutta A, Flores AR, Revell PA, Owens L (2018) Neonatal bacteremia and cutaneous lesions caused by Photorhabdus luminescens: a rare gram-negative bioluminescent bacterium. J Pediatric Infect Dis Soc 7(3):e182-e184

Eckstein S, Dominelli N, Brachmann A, Heermann R (2019) Phenotypic heterogeneity of the insect pathogen Photorhabdus luminescens: insights into the fate of secondary cells. Appl Environ Microbiol 85(22): $01910-\mathrm{e} 01919$

Euzéby JP, Boemare NE (2000) The modern Latin word rhabdus belongs to the feminine gender, inducing necessary corrections according to rules $65(2), 12 \mathrm{c}(1)$ and $13 \mathrm{~b}$ of the bacteriological code (1990 revision). Int J Syst Evol Microbiol 50(4):1691-1692

Farmer JJ, Jorgensen JH, Grimont PA, Akhurst RJ, Poinar GO, Ageron E, Pierce GV, Smith JA, Carter G. P, Wilson KL (1989) Xenorhabdus luminescens (DNA hybridization group 5) from human clinical specimens. J Clin Microbiol 27(7):1594-1600

Ferreira T, van Reenen CA, Endo A, Sproer C, Malan AP, Dicks LMT (2013a) Description of Xenorhabdus khoisanae sp. nov., the symbiont of the entomopathogenic nematode Steinernema khoisanae. Int J Syst Evol Microbiol 63(9):3220-3224

Ferreira T, van Reenen CA, Pages S, Tailliez P, Malan AP, Dicks LMT (2013b) Photorhabdus luminescens subsp. noenieputensis subsp. nov., a symbiotic bacterium associated with a novel Heterorhabditis species related to Heterorhabditis indica. Int $\mathrm{J}$ Syst Evol Microbiol 63(5):1853-1858

Ferreira T, van Reenen CA, Endo A, Tailliez P, Pages S, Sproer C, Malan AP, Dicks LMT (2014) Photorhabdus heterorhabditis sp. nov., a symbiont of the entomopathogenic nematode Heterorhabditis zealandica. Int J Syst Evol Microbiol 64(5):1540-1545 
Fischer-Le Saux M, Viallard V, Brunel B, Normand P, Boemare NE (1999) Polyphasic classification of the genus Photorhabdus and proposal of new taxa: P. luminescens subsp. luminescens subsp. nov., P. luminescens subsp. akhurstii subsp. nov., $P$. luminescens subsp. laumondii subsp. nov., P. temperata sp. nov., $P$. temperata subsp. temperatas ubsp. nov. and $P$. asymbiotica sp. nov. Int J Syst Bacteriol 49(4):1645-1656

Gerrard JG, Stevens RP (2017) A review of clinical cases of infection with Photorhabdus asymbiotica. Curr Top Microbiol Immunol 402: 179-191

Gerrard JG, Vohra R, Nimmo GR (2003) Identification of Photorhabdus asymbiotica in cases of human infection. Commun Dis Intell Q Rep 27(4):540-541

Gerrard J, Waterfield N, Vohra R, ffrench-Constant R (2004) Human infection with Photorhabdus asymbiotica: an emerging bacterial pathogen. Microbes Infect 6(2):229-237

Gerrard JG, Joyce SA, Clarke DJ, ffrench-Constant RH, Nimmo GR, Looke DF, Feil EJ, Pearce L, Waterfield NR (2006) Nematode symbiont for Photorhabdus asymbiotica. Emerg Infec Dis 12(10):15621564

Gerrard J, Waterfield N, Sanchez-Contreeras M (2011) Photorhabdus asymbiotica: shedding light on a human pathogenic bioluminescent bacterium. Clin Microbiol Newsl 33:103-109

Glaeser SP, Kämpfer P (2015) Multilocus sequence analysis (MLSA) in prokaryotic taxonomy. Syst Appl Microbiol 38(4):237-245

Glaeser SP, Tobias NJ, Thanwisai A, Chantratita N, Bode HB, Kampfer P (2017) Photorhabdus luminescens subsp. namnaonensis subsp. nov., isolated from Heterorhabditis baujardi nematodes. Int J Syst Evol Microbiol 67:1046-1051

Glare TR, Jurat-Fuentes J-L, O'Callaghan M (2017) Basic and applied research: entomopathogenic bacteria. In: Lacey LA (ed) Microbial control of insect and mite pests. Academic Press, pp 47-67

Godjo A, Afouda L, Baimey H, Decraemer W, Willems A (2018) Molecular diversity of Photorhabdus and Xenorhabdus bacteria, symbionts of Heterorhabditis and Steinernema nematodes retrieved from soil in Benin. Arch Microbiol 200(4):589-601

Goodrich-Blair H, Clarke DJ (2007) Mutualism and pathogenesis in Xenorhabdus and Photorhabdus. Two roads to the same destination. Mol Microbiol 64(2):260-268

Grewal PS, Selvan S, Gaugler R (1994) Thermal adaptation of entomopathogenic nematodes. Niche breadth for infection, establishment, and reproduction. J Therm Biol 19(4):245-253

Grewal PS, Lewis EE, Gaugler R (1997) Response of infective stage parasites (Nematoda: Steinernematidae) to volatile cues from infected hosts. J Chem Ecol 23(2):503-515

Hapeshi A, Waterfield NR (2017) Photorhabdus asymbiotica as an insect and human pathogen. Curr Top Microbiol Immunol 402:159-177

Hazir S, Stackebrandt E, Lang E, Schumann P, Ehlers R-U, Keskin N (2004) Two new subspecies of Photorhabdus luminescens, isolated from Heterorhabditis bacteriophora (Nematoda: Heterorhabditidae): Photorhabdus luminescens subsp. kayaii subsp. nov. and Photorhabdus luminescens subsp. thracensis subsp. nov. Syst Appl Microbiol 27(1):36-42

Henry LM, Peccoud J, Simon JC, Hadfield JD, Maiden MJ, Ferrari J, Godfray HC (2013) Horizontally transmitted symbionts and host colonization of ecological niches. Curr Biol 9(17):1713-1717

Herbert EE, Goodrich-Blair H (2007) Friend and foe: the two faces of Xenorhabdus nematophila. Nat Rev Microbiol 5(8):634-646

Hillman K, Goodrich-Blair H (2016) Are you my symbiont? Microbial polymorphic toxins and antimicrobial compounds as honest signals of beneficial symbiotic defensive traits. Curr Opin Microbiol 31: $184-190$

Hiltpold I (2015) Prospects in the application technology and formulation of entomopathogenic nematodes for biological control of insect pests. In: Campos-Herrera R (ed) Nematode pathogenesis of insects and other pests: ecology and applied technologies for sustainable plant and crop protection. Springer International Publishing, Neuchâtel, pp 187-206

Hinchliffe SJ, Hares M, Dowling A, ffrench-Constant R (2010) Insecticidal toxins from the Photorhabdus and Xenorhabdus bacteria. Open Toxinol J 3:83-100

Husnik F, Chrudimský T, Hypša V (2011) Multiple origins of endosymbiosis within the Enterobacteriaceae ( $\gamma$-Proteobacteria): convergence of complex phylogenetic approaches. BMC Biol 91:87

Imhoff JF (2005) Enterobacteriales. In: Brenner DJ, Krieg NR, Staley JT, Garrity GM, Boone DR, Vos P, de Goodfellow M, Rainey FA, Schleifer K-H (eds) Bergey’s manual ${ }^{\circledR}$ of systematic bacteriology. Springer US, Boston, pp 587-850

Kajla MK, Barrett-Wilt GA, Paskewitz S (2019) Bacteria: a novel source for potent mosquito feeding-deterrents. Sci Adv 5(1):eaau6141

Kämpfer P, Tobias NJ, Ke LP, Bode HB, Glaeser SP (2017) Xenorhabdus thuongxuanensis sp. nov. and Xenorhabdus eapokensis sp. nov., isolated from Steinernema species. Int J Syst Evol Microbiol 67(5):1107-1114

Kazimierczak W, Sajnaga E, Skowronek M, Kreft AM, Skrzypek HW, Wiater A (2016) Molecular and phenotypic characterization of Xenorhabdus bovienii symbiotically associated with Steinernema silvaticum. Arch Microbiol 198(10):995-1003

Kazimierczak W, Skrzypek H, Sajnaga E, Skowronek M, Waśko A, Kreft A (2017) Strains of Photorhabdus spp. associated with polish Heterorhabditis isolates: their molecular and phenotypic characterization and symbiont exchange. Arch Microbiol 199(7):979-989

Koeppel A, Perry EB, Sikorski J, Krizanc D, Warner A, Ward DM, Rooney AP, Brambilla E, Connor N, Ratcliff RM, Nevo E, Cohan FM (2008) Identifying the fundamental units of bacterial diversity: a paradigm shift to incorporate ecology into bacterial systematics. Proc Natl Acad Sci U S A 105(7):2504-2509

Koppenhöfer HS (2007) Bacterial symbionts of Steinernema and Heterorhabditis. In: Nguyen KB, Hunt DJ (eds) Entomopathogenic nematodes: systematics, phylogeny and bacterial symbionts. Brill Academic Publishers (nematology monographs and perspectives, 5), Leiden-Boston, pp 735-808

Koppenhöfer HS, Gaugler R (2009) Entomopathogenic nematode and bacteria mutualism. In: White J, Torres M (eds) Defensive mutualism in microbial symbiosis. CRC Press, Boca Raton, pp 99-116

Koppenhöfer AM, Kaya HK (1996) Coexistence of two steinernematid nematode species (Rhabditida: Steinernematidae) in the presence of two host species. Appl Soil Ecol 4:221-230

Kumari P, Mahapatro GK, Banerjee N, Sarin NB (2015) Ectopic expression of GroEL from Xenorhabdus nematophila in tomato enhances resistance against Helicoverpa armigera and salt and thermal stress. Transgenic Res 24(5):859-873

Kuwata R, Yoshiga T, Yoshida M, Kondo E (2008) Mutualistic association of Photorhabdus asymbiotica with Japanese heterorhabditid entomopathogenic nematodes. Microbes Infect 10(7):734-741

Kuwata R, Qiu LH, Wang W, Harada Y, Yoshida M, Kondo E, Yoshiga T (2013) Xenorhabdus ishibashii sp. nov., isolated from the entomopathogenic nematode Steinernema aciari. Int J Syst Evol Microbiol 63:1690-1695

Lee M-M, Stock SP (2010a) A multigene approach for assessing evolutionary relationships of Xenorhabdus spp. (gamma-Proteobacteria), the bacterial symbionts of entomopathogenic Steinernema nematodes. J Invertebr Pathol 104(2):67-74

Lee M-M, Stock SP (2010b) A multilocus approach to assessing coevolutionary relationships between Steinernema spp. (Nematoda. Steinernematidae) and their bacterial symbionts Xenorhabdus spp. ( $\gamma$-Proteobacteria: Enterobacteriaceae). Syst Parasitol 77(1):1-12

Lee I, Ouk Kim Y, Park SC, Chun J (2016) OrthoANI: An improved algorithm and software for calculating average nucleotide identity. Int J Syst Evol Microbiol 66(2):1100-1103

Lengyel K, Lang E, Fodor A, Szallas E, Schumann P, Stackebrandt E (2005) Description of four novel species of Xenorhabdus, family 
Enterobacteriaceae: Xenorhabdus budapestensis sp. nov., Xenorhabdus ehlersii sp. nov., Xenorhabdus innexi sp. nov., and Xenorhabdus szentirmaii sp. nov. Syst Appl Microbiol 28(2):115122

Liu J, Berry R, Poinar G, Moldenke A (1997) Phylogeny of Photorhabdus and Xenorhabdus species and strains as determined by comparison of partial $16 \mathrm{~S}$ rRNA gene sequences. Int J Syst Bacteriol 47(4):948-951

Machado RAR, Wüthrich D, Kuhnert P, Arce CCM, Thönen L, Ruiz C, Zhang X, Robert CAM, Karimi J, Kamali S, Ma J, Bruggmann R, Erb M (2018) Whole-genome-based revisit of Photorhabdus phylogeny: proposal for the elevation of most Photorhabdus subspecies to the species level and description of one novel species Photorhabdus bodei sp. nov., and one novel subspecies Photorhabdus laumondii subsp. clarkei subsp. nov. Int J Syst Evol Microbiol 68(8):2664-2681

Machado RAR, Bruno P, Arce CCM, Liechti N, Köhler A, Bernal J, Bruggmann R, Turlings TCJ (2019) Photorhabdus khanii subsp. guanajuatensis subsp. nov., isolated from Heterorhabditis atacamensis, and Photorhabdus luminescens subsp. Mexicana subsp. nov., isolated from Heterorhabditis mexicana entomopathogenic nematodes. Int J Syst Evol Microbiol 69(3):652-661

Maher AM, Asaiyah MA, Brophy C, Griffin CT (2017) An entomopathogenic nematode extends its niche by associating with different symbionts. Microb Ecol 73(1):211-223

Maiden MC, Bygraves JA, Feil E, Morelli G, Russell JE, Urwin R, Zhang Q, Zhou J, Zurth K, Caugant DA, Feavers IM, Achtman M, Spratt BG (1998) Multilocus sequence typing: a portable approach to the identification of clones within populations of pathogenic microorganisms. Proc Natl Acad Sci U S A 95(6):3140-3145

Maneesakorn P, An R, Daneshvar H, Taylor K, Bai X, Adams BJ, Grewal PS, Chandrapatya A (2011) Phylogenetic and cophylogenetic relationships of entomopathogenic nematodes (Heterorhabditis: Rhabditida) and their symbiotic bacteria (Photorhabdus: Enterobacteriaceae). Mol Phylogenet Evol 59(2):271-280

McMullen JG, McQuade R, Ogier J-C, Pages S, Gaudriault S, Stock SP (2017a) Variable virulence phenotype of Xenorhabdus bovienii (gamma-Proteobacteria. Enterobacteriaceae) in the absence of their vector hosts. Microbiology 163(4):510-522

McMullen JG, Peterson BF, Forst S, Goodrich-Blair H, Stock SP (2017b) Fitness costs of symbiont switching using entomopathogenic nematodes as a model. BMC Evol Biol 17(1):100

Meli S, Bashey F (2018) Trade-off between reproductive and anticompetitor abilities in an insect-parasitic nematode-bacteria symbiosis. Ecol Evol 8:10847-10856

Mulley G, Beeton ML, Wilkinson P, Vlisidou I, Ockendon-Powell N, Hapeshi A, Tobias NJ, Nollmann FI, Bode HB, van den Elsen J, ffrench-Constant RH, Waterfield NR (2015) From insect to man: Photorhabdus sheds light on the emergence of human pathogenicity. PLoS One 10(12):e0144937

Murfin KE, Dillman AR, Foster JM, Bulgheresi S, Slatko BE, Sternberg PW, Goodrich-Blair H (2012) Nematode-bacterium symbioses - cooperation and conflict revealed in the "omics" age. Biol Bull 223(1): $85-102$

Murfin KE, Lee M-M, Klassen JL, BR MD, Larget B, Forst S, Stock SP, Currie CR, Goodrich-Blair H (2015a) Xenorhabdus bovienii strain diversity impacts coevolution and symbiotic maintenance with Steinernema spp. nematode hosts. mBio 6(3):e00076

Murfin KE, Whooley AC, Klassen JL, Goodrich-Blair H (2015b) Comparison of Xenorhabdus bovienii bacterial strain genomes reveals diversity in symbiotic functions. BMC Genomics 16:889

Nadler SA, Bolotin E, Stock SP (2006) Phylogenetic relationships of Steinernema Travassos, 1927 (Nematoda: Cephalobina: Steinernematidae) based on nuclear, mitochondrial and morphological data. Syst Parasitol 63:161-181
Nishimura Y, Hagiwara A, Suzuki T, Yamanaka S (1994) Xenorhabdus japonicus sp. nov. associated with the nematode Steinernema kushidai. World J Microb Biot 10(2):207-210

Orozco RA, Hill T, Stock SP (2013) Characterization and phylogenetic relationships of Photorhabdus luminescens subsp. sonorensis ( $\gamma$ Proteobacteria: Enterobacteriaceae), the bacterial symbiont of the entomopathogenic nematode Heterorhabditis sonorensis (Nematoda: Heterorhabditidae). Curr Microbiol 66(1):30-39

Osimani A, Milanović V, Cardinali F, Garofalo C, Clementi F, Pasquini M, Riolo P, Ruschioni S, Isidoro N, Loreto N, Franciosi E, Tuohy K, Petruzzelli A, Foglini M, Gabucci C, Tonucci F, Aquilanti L (2018) The bacterial biota of laboratory-reared edible mealworms (Tenebrio molitor L.): from feed to frass. Int J Food Microbiol 272:49-60

Peat S, Adams B (2008) Natural selection on the luxA gene of bioluminescent bacteria. Symbiosis 46(2):101-108

Peat SM, ffrench-Constant RH, Waterfield NR, Marokházi J, Fodor A, Adams BJ (2010) A robust phylogenetic framework for the bacterial genus Photorhabdus and its use in studying the evolution and maintenance of bioluminescence: a case for $16 \mathrm{~S}$, $g y r B$, and $g \ln A$. Mol Phylogenet Evol 57(2):728-740

Peters A (1996) The natural host range of Steinernema and Heterorhabditis spp. and their impact on insect populations. Biocontrol Sci Tech 6(3):389-402

Plichta KL, Joyce SA, Clarke D, Waterfield N, Stock SP (2009) Heterorhabditis gerrardi n. sp. (Nematoda: Heterorhabditidae): the hidden host of Photorhabdus asymbiotica (Enterobacteriaceae: gamma-Proteobacteria). J Helminthol 83(4):309-320

Poinar GO, Grewal PS (2012) History of entomopathogenic nematology. J Nematol 44(2):153-161

Poinar GO, Thomas GM (1965) A new bacterium, Achromobacter nemathopilus sp. nov. (Achromobacteriaceae: Eubacteriales), associated with a nematode. Int B Bact Nomencl T 15:249-252

Poinar GOJ, Thomas GM (1966) Significance of Achromobacter nematophilus Poinar and Thomas (Achromobacteracaea: Eubacteriales) in the development of the nematode, DD-126 (Neoplectana sp. Steinernematidae). Parasitology 56:385-390

Půža V, Mráček Z (2010) Mechanism of coexistence of two sympatric entomopathogenic nematodes, Steinernema affine and S. kraussei (Nematoda: Steinernematidae) in a central European oak woodland soil. Appl Soil Ecol 45:65-70

Rosselló-Mora R, Amann R (2001) The species concept for prokaryotes. FEMS Microbiol Rev 25(1):39-67

Sajnaga E, Kazimierczak W, Skowronek M, Lis M, Skrzypek T, Waśko A (2018) Steinernema poinari (Nematoda: Steinernematidae): a new symbiotic host of entomopathogenic bacteria Xenorhabdus bovienii. Arch Microbiol 200(9):1307-1316

Sergeant M, Baxter L, Jarrett P, Shaw E, Ousley M, Winstanley C, Morgan JAW (2006) Identification, typing, and insecticidal activity of Xenorhabdus isolates from entomopathogenic nematodes in United Kingdom soil and characterization of the xpt toxin loci. Appl Environ Microb 72(9):5895-5907

Sicard M, Ferdy JB, Pages S, Le Brun N, Godelle B, Boemare N, Moulia C (2004) When mutualists are pathogens: an experimental study of the symbioses between Steinernema (entomopathogenic nematodes) and Xenorhabdus (bacteria). J Evol Biol 17(5):985-993

Sicard M, Ramone H, Le Brun N, Pagès S, Moulia C (2005) Specialization of the entomopathogenic nematode Steinernema scapterisci with its mutualistic Xenorhabdus symbiont. Naturwissenschaften. 92(10):472-476

Snyder H, Stock PS, Kim S-K, Flores-Lara Y, Forst S (2007) New insight into the colonization and release process of Xenorhabdus nematophila and the morphology and ultrastructure of the bacterial recepacle of its nematode host, Steinernema carpocapsae. Appl Environ Microb 73(16):5338-5346

Somvanshi VS, Lang E, Ganguly S, Swiderski J, Saxena AK, Stackebrandt E (2006) A novel species of Xenorhabdus, family 
Enterobacteriaceae: Xenorhabdus indica sp. nov., symbiotically associated with entomopathogenic nematode Steinernema thermophilum Ganguly and Singh, 2000. Syst Appl Microbiol 29(7):519-525

Spiridonov SE, Reid AP, Podrucka K, Subbotin SA, Moens M (2004) Phylogenetic relationships within the genus Steinernema (Nematoda: Rhabditida) as inferred from analyses of sequences of the ITSI-5.8S-ITS2 region of rDNA and morphological features. Nematology 6:547-566

Stackebrandt E, Ebers J (2006) Taxonomic parameters revisited: tarnished gold standards. Microbiol Today 8(4):6-9

Stackebrandt E, Frederiksen W, Garrity GM, Grimont PA, Kämpfer P, Maiden MC, Nesme X, Rosselló-Mora R, Swings J, Trüper HG, Vauterin L, Ward AC, Whitman WB (2002) Report of the ad hoc committee for the re-evaluation of the species definition in bacteriology. Int J Syst Evol Microbiol 52(3):1043-1047

Stock SP (2005) Insect-parasitic nematodes. From lab curiosities to model organisms. J Invertebr Pathol 89(1):57-66

Stock SP (2015) Diversity, biology and evolutionary relationships. In: Campos-Herrera R (ed) Nematode pathogenesis of insects and other pests: ecology and applied technologies for sustainable plant and crop protection. Springer International Publishing, Neuchâtel, Switzerland, pp 3-27

Stock SP, Goodrich-Blair H (2008) Entomopathogenic nematodes and their bacterial symbionts. The inside out of a mutualistic association. Symbiosis 46(2):65-75

Stock SP, Kusakabe A, Orozco RA (2017) Secondary metabolites produced by Heterorhabditis symbionts and their application in agriculture: what we know and what to do next. J Nematol 49(4):373383

Tailliez P, Pages S, Ginibre N, Boemare N (2006) New insight into diversity in the genus Xenorhabdus, including the description of ten novel species. Int J Syst Evol Microbiol 56(12):2805-2818

Tailliez P, Laroui C, Ginibre N, Paule A, Pages S, Boemare N (2010) Phylogeny of Photorhabdus and Xenorhabdus based on universally conserved protein-coding sequences and implications for the taxonomy of these two genera. Proposal of new taxa. X. vietnamensis sp. nov., P. luminescens subsp. caribbeanensis subsp. nov., $P$. luminescens subsp. hainanensis subsp. nov., P. temperata subsp. khanii subsp. nov., $P$. temperata subsp. tasmaniensis subsp. nov., and the reclassification of $P$. luminescens subsp. thracensis as P. temperata subsp. thracensis comb. nov. Int J Syst Evol Microbiol 60(8):1921-1937

Tailliez P, Pages S, Edgington S, Tymo LM, Buddie AG (2012) Description of Xenorhabdus magdalenensis sp. nov., the symbiotic bacterium associated with Steinernema australe. Int J Syst Evol Microbiol 62(8):1761-1765

Thanwisai A, Tandhavanant S, Saiprom N, Waterfield NR, Ke Long P, Bode HB, Peacock SJ, Chantratita N (2012) Diversity of
Xenorhabdus and Photorhabdus spp. and their symbiotic entomopathogenic nematodes from Thailand. PLoS One 7(9):e43835

Thomas GM, Poinar GO (1979) Xenorhabdus gen. nov., a genus of entomopathogenic nematophilic bacteria of the family Enterobacteriaceae. Int J Syst Bacteriol 29:352-360

Tobias NJ, Shi YM, Bode HB (2018) Refining the natural product repertoire in entomopathogenic bacteria. Trends Microbiol 26(10):833840

Tóth T, Lakatos T (2008) Photorhabdus temperata subsp. cinerea subsp. nov., isolated from Heterorhabditis nematodes. Int J Syst Evol Microbiol 58(11):2579-2581

Vandamme P, Pot B, Gillis M, de Vos P, Kersters K, Swings J (1996) Polyphasic taxonomy, a consensus approach to bacterial systematics. Microbiol Rev 60(2):407-438

Waterfield NR, Daborn PJ, ffrench-Constant RH (2002) Genomic islands in Photorhabdus. Trends Microbiol 10:541-545

Wayne LG, Moore WEC, Stackebrandt E, Kandler O, Colwell RR, Grimont PAD, Kandler O, Krichersky MI, Moore LH, More WEC, Murray RGE, Stackebrandt E, Starr MP, Trüper HG (1987) Report of the ad hoc committee on reconciliation of approaches to bacterial systematics. Int J Syst Microbiol 37:463-464

Wilkinson P, Waterfield NR, Crossman L, Corton C, Sanchez-Contreras M, Vlisidou I, Barron A, Bignell A, Clark L, Ormond D, Mayho M, Bason N, Smith F, Simmonds M, Churcher C, Harris D, Thompson NR, Quail M, Parkhill J, ffrench-Constant RH (2009) Comparative genomics of the emerging human pathogen Photorhabdus asymbiotica with the insect pathogen Photorhabdus luminescens. BMC Genomics 10(1):302

Wilkinson P, Paszkiewicz K, Moorhouse A, Szubert JM, Beatson S, Gerrard J, Waterfield NR, ffrench-Constant RH (2010) New plasmids and putative virulence factors from the draft genome of an Australian clinical isolate of Photorhabdus asymbiotica. FEMS Microbiol Lett 309(2):136-143

Xue Y, Wang M, Zhao P, Quan C, Li X, Wang L, Gao W, Li J, Zu X, Fu D, Feng S, Li P (2018) Gram-negative bacilli-derived peptide antibiotics developed since 2000. Biotechnol Lett 40(9-10):1271-1287

Yooyangket T, Muangpat P, Polseela R, Tandhavanant S, Thanwisai A, Vitta A (2018) Identification of entomopathogenic nematodes and symbiotic bacteria from Nam Nao National Park in Thailand and larvicidal activity of symbiotic bacteria against Aedes aegypti and Aedes albopictus. PLoS One 13(4):e0195681

Zhang H, Mao J, Liu F, Zeng F (2012) Expression of a nematode symbiotic bacterium-derived protease inhibitor protein in tobacco enhanced tolerance against Myzus persicae. Plant Cell Rep 31(11): 1981-1989

Publisher's note Springer Nature remains neutral with regard to jurisdictional claims in published maps and institutional affiliations. 